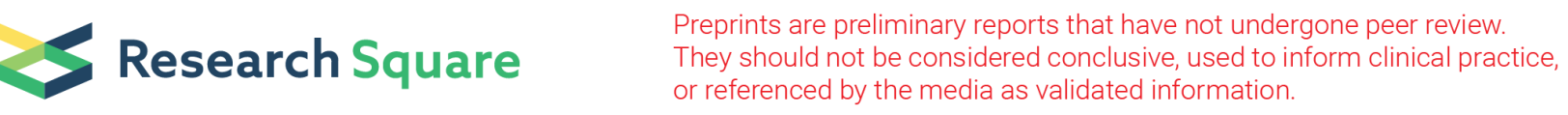

\title{
The Effectiveness Of Raising Hong Kong Parents' Awareness Of Antimicrobial Resistance Through An Educational Program With Peer Support On Social Media: A Pilot Study
}

Peggy P.L. Or ( $\sim$ peggyor@yahoo.com )

Education University of Hong Kong https://orcid.org/0000-0001-6611-2724

Patricia T.Y. Ching

University of Hong Kong

\section{Research}

Keywords: self-efficacy, antibiotic, GSE, education

Posted Date: July 30th, 2020

DOI: https://doi.org/10.21203/rs.3.rs-44737/v1

License: (c) (1) This work is licensed under a Creative Commons Attribution 4.0 International License.

Read Full License 


\section{Abstract}

Objective: To test whether parents' self-efficacy for appropriate antibiotic use could be improved through the education program with peer support on social media.

Methods: A cluster randomized controlled trial with two-arms were implemented. The intervention program consisted of two weekly sessions and each session lasted for 90 minutes. A total of 48 parents had participated in the program. Parental knowledge, attitude, and their social network were measured before and after the program using the Parental Perception on Antibiotics (PAPA) scale and the GSE scale to assess differences between and within the intervention and control groups.

Findings: All parents in the intervention group disagreed that antibiotics are effective against infections (virus, bacteria and fungi), as compared to a mere $40 \%$ in the control group. All parents in the intervention group and $85 \%$ of the control group disagreed that they should reduce the dose of antibiotics when their children were recovering. The test was statistically significant $(p=0.039)$. There was a significant difference and a strong negative correlation between social media and the parents' belief that antibiotics could be stopped when their children felt better, with Pearson coefficient of -0.78 and $p=0.001$. On the whole, there was no significant difference between the two groups with respect to the GSE scale

Conclusion: Based on the findings in this pilot study, a further study based on the education program with enhancement and peer support can be implemented in a large scale with a positive expectation of reducing antimicrobial resistance.

\section{Introduction}

Overuse and misuse of antibiotics are the main causes of antimicrobial resistance which harm both individuals and the community. Many doctors felt that they were pressurized by patients to prescribe antibiotics for viral infections such as influenza or cold ${ }^{1}$. The 2010 Eurobarometer found that over $50 \%$ of adults still believed antibiotics could treat colds. ${ }^{2}$ A 2015 Hong Kong study found that $7.8 \%$ of the interviewees bought antibiotics without a prescription. ${ }^{3}$ It is also evident that suboptimum compliance of antibiotic use, including taking leftover antibiotics from previous treatment courses and sharing unused antibiotics among household members or friends, is common in both developed and developing countries. ${ }^{4}$ In particular, it has been found that antibiotics are commonly prescribed for children with medical conditions, including viral respiratory infections for which they provide no benefit. ${ }^{5}$ Inappropriate use of antibiotics in children is a known issue and has generated widespread social concern. ${ }^{6}$ Besides causing antimicrobial resistance, it also leads to the development of adverse gastrointestinal effects in children. ${ }^{7}$ To reduce antibiotic overuse in children, strategies need to be developed by first assessing parents' knowledge in respiratory illnesses and their treatment. ${ }^{7}$ Parents, as carers of their children, have a key role to play. However, they have poor knowledge about antibiotics and diseases. ${ }^{8}$ Some parents even self-medicate their children. In view of this harmful behavior, parents should be educated with 
accurate information on both antibiotics and infectious diseases instead of having access to antibiotics without prescriptions. ${ }^{9}$

To induce parents' positive behavior change in health needs of their children, in this study, we hypothesized that peer support can motivate and reinforce their learning efforts as antibiotics consumers. We conducted a pilot study in a small sample of kindergartens to examine the participating parents' ability to comprehend and follow antibiotic usage information before and after an education program whilst receiving peer support through an online social platform to achieve behavior and attitude change in antibiotic use. Our objective was to test whether parents' self-efficacy for appropriate antibiotic use could be improved through this program.

\section{Methods}

\section{Subjects}

A cluster randomized controlled trial with two-arms were implemented to assess the efficacy of behavior change in decisions on antibiotic use in relation to childhood infection. For confidentiality, computer generated numbers were used as codes to recruit kindergartens and parents of kindergarteners aged under 7 , as clusters, to the intervention and control groups. The subjects were selected according to the inclusion criterion that they were parents of kindergarteners aged below 7. Kindergartens were selected from the same region to ensure that the demographics of the two groups were comparable.

Randomization was implemented by putting the sealed codes for selection inside a paper bag. The sample was then drawn randomly by an individual who was not associated with the study to prevent selection and confounding biases.

The parents in the intervention group were asked to join an education program on antibiotic usage and a peer support group, whereas those in the control group were only given information leaflets on antibiotics from the Centre for Health Protection.

\section{Procedure}

The intervention program consisted of two weekly sessions and each session lasted for 90 minutes. The participating kindergartens sent training reminders to the parents one week before each session. Interventions addressing antibiotic use were administrated in two formats: a functional session (Week 1:

the basic knowledge on viral and bacterial infections) and an interactive session (Week 2: case studies on consulting behavior, management planning and experience sharing). The parents in the intervention group, together with a pharmacist and an infection control nurse, would join a Facebook Page of Antibiotic Use at the beginning of the program. This page would allow these participants to build a social network to send and receive instant online advice amongst the team members on antibiotic issues. On the online platform, they could interact with one another, thus strengthening parent-to-parent support. 
To facilitate the assessment of the participating parents, survey packets containing the questionnaires and reminders to parents were sent to both the intervention and control groups from the participating kindergartens for use before the 2-week period. One participating parent of each child was asked to complete one set of questionnaires before and after the program. The participants were instructed to fill out the questionnaires only once irrespective of the number of children attending the same kindergarten. The questionnaires took 20 minutes to complete.

Approval from the Research Ethics Committee was sought before recruitment and written consents were obtained from the parents concerned. The parents were informed that withdrawal at any time would not result in any negative consequences. All data were protected with passwords. Only the researcher and her team had access to the datasets to prevent any leakage of sensitive information.

\section{Measures}

To measure peer support, the peer support outcome protocol adapted from the outcome evaluation indicators ${ }^{10}$ was used. Specific outcomes that are available in the protocol include: demographics, service use, program satisfaction, participation in a discussion group. Parental knowledge, attitude, and their social network were measured before and after the program using the Parental Perception on Antibiotics (PAPA) scale and the GSE scale to assess differences, if any, between and within the intervention and control groups.

The PAPA scale was administered to pre-test and post-test the participants' capability in comprehending and acting on antibiotics-related information (functional: the basic skills in understanding antimicrobial drug knowledge), Cronbach's alpha $=0.78$. The PAPA scale consists of 4 sections: 1 ) Children's health, 2) Antibiotics and health information, 3) Experience with antibiotics and health professionals, and 4) Personal attitudes and beliefs about antibiotics.

The PAPA scale has 32 items measuring the factors influencing the overuse of antibiotics in children, especially those with upper respiratory tract infections. Parents were asked to rate on a 5-point Likert scale ranging from strongly disagree to strongly agree or from never to always on child health-related history, including the number of cold episodes and antibiotics (courses) used for the youngest child during the previous year (ranging from never to more than 6 times a year), whether any of the children in the family has ever had a serious infectious disease or a chronic disease, and items relating to factors influencing the parental use of antibiotics including knowledge and beliefs, behaviors, adherence, information seeking, awareness about antibiotics resistance, and their perception about doctors' prescribing behavior. ${ }^{5}$ The parents in both groups were required to complete the self-reporting Generalized Self-Efficacy scale (GSE) before and after the program. GSE is a 10-item scale with a score ranging from 1 to 4 for each question. Higher scores indicate stronger parental belief in self-efficacy. The Cronbach's alpha coefficient for the entire scale was 0.80 and the test-retest reliability coefficient was $0.69 .{ }^{11}$

\section{Statistical analysis}


Descriptive statistics was used to group the numerical and categorical data of the study. Chi-square tests were undertaken to ascertain differences in baseline characteristics across groups of categorical data. Independent t tests were run to investigate differences in outcomes from parents' health behavior at baseline and follow-up. Mann Whitney $U$ test was conducted to compare the difference of attitude of antibiotic use between the intervention and control groups. Correlation analysis was performed to analyze the relationship between social support and parents' personal attitude towards antibiotic use. For the estimation of effects, $95 \%$ confidence intervals were provided. The statistical significance for all tests was set at $p<0.05$.

\section{Results}

A total of 48 parents had participated in the program with four parents dropped out from the control group because of sickness or personal issues. As a result, 24 parents participated in the intervention group and 20 in the control group. The sex distribution of the participants was $3(12.5 \%)$ males and 21 (87.5\%) females for the intervention group, and 3 (15\%) males and 17 (85\%) females for the control group. On age range, it was 22 to 43 and 21 to 45 for the intervention and control groups respectively. No significant demographic differences were found between the two groups.

In Sect. 1 of the PAPA scale which covered children's health records, over half of the parents reported that the number of colds their youngest children had in the past year -2 to 3 for the intervention group and 3 to 4 for the control group. Nearly half of the parents in both groups said that their youngest children took antibiotics in the past year-once a year and 2 to 3 times in the last year for the intervention and control group respectively. All parents in the intervention group and $30 \%$ in the control group responded that their children received seasonal influenza vaccine in the past 6 months. At the end of the second week of the training, all parents in the intervention group disagreed that antibiotics are effective against infections (virus, bacteria and fungi), as compared to a mere $40 \%$ in the control group. From the Mann Whitney $\mathrm{U}$ test performed, a significant difference $(p=0.024)$ (Table 1$)$ was found. As shown in Table 2, all parents in the intervention group and $85 \%$ of the control group disagreed that they should reduce the dose of antibiotics when their children were recovering. The test was statistically significant $(p=0.039)$. 
Table 1

Questions on proper antibiotic use with PAPA scale

\begin{tabular}{|c|c|c|c|c|c|c|c|c|}
\hline & Question & Group & $\begin{array}{l}\text { Strongly } \\
\text { disagree } \\
(\%)\end{array}$ & $\begin{array}{l}\text { Disagree } \\
\text { (\%) }\end{array}$ & $\begin{array}{l}\text { Neutral } \\
\text { (\%) }\end{array}$ & $\begin{array}{l}\text { Agree } \\
(\%)\end{array}$ & $\begin{array}{l}\text { Strongly } \\
\text { agree } \\
\text { (\%) }\end{array}$ & $\begin{array}{l}P \\
\text { value }\end{array}$ \\
\hline \multirow[t]{2}{*}{1.} & \multirow{2}{*}{$\begin{array}{l}\text { Common cold: } \\
\text { need to take } \\
\text { antibiotics }\end{array}$} & Intervention & 75 & 25 & 0 & 0 & 0 & \multirow[t]{2}{*}{0.142} \\
\hline & & Control & 35 & 55 & 10 & 0 & 0 & \\
\hline \multirow[t]{2}{*}{2.} & \multirow{2}{*}{$\begin{array}{l}\text { Sore throat: } \\
\text { need to take } \\
\text { antibiotics }\end{array}$} & Intervention & 25 & 0 & 50 & 0 & 25 & \multirow[t]{2}{*}{0.053} \\
\hline & & Control & 25 & 45 & 30 & 0 & 0 & \\
\hline \multirow[t]{2}{*}{3.} & \multirow{2}{*}{$\begin{array}{l}\text { Antibiotics are } \\
\text { used to treat } \\
\text { bacterial } \\
\text { infections }\end{array}$} & Intervention & 0 & 25 & 0 & 50 & 25 & \multirow[t]{2}{*}{0.770} \\
\hline & & Control & 0 & 10 & 25 & 50 & 15 & \\
\hline \multirow[t]{2}{*}{4.} & \multirow{2}{*}{$\begin{array}{l}\text { Antibiotics are } \\
\text { used to treat } \\
\text { viral infections }\end{array}$} & Intervention & 50 & 25 & 0 & 0 & 25 & \multirow[t]{2}{*}{0.222} \\
\hline & & Control & 10 & 10 & 30 & 50 & 0 & \\
\hline \multirow[t]{2}{*}{5.} & \multirow{2}{*}{$\begin{array}{l}\text { Antibiotics can } \\
\text { cure all types } \\
\text { of infections } \\
\text { (viruses, } \\
\text { bacteria and } \\
\text { fungi) }\end{array}$} & Intervention & 50 & 50 & 0 & 0 & 0 & \multirow[t]{2}{*}{$0.024^{*}$} \\
\hline & & Control & 10 & 30 & 40 & 20 & 0 & \\
\hline \multirow[t]{2}{*}{6.} & \multirow{2}{*}{$\begin{array}{l}\text { Antibiotics help } \\
\text { treat children } \\
\text { with colds }\end{array}$} & Intervention & 50 & 25 & 25 & 0 & 0 & \multirow[t]{2}{*}{0.077} \\
\hline & & Control & 10 & 30 & 30 & 30 & 0 & \\
\hline \multirow[t]{2}{*}{7.} & \multirow{2}{*}{$\begin{array}{l}\text { Antibiotics can } \\
\text { be harmful to } \\
\text { human health }\end{array}$} & Intervention & 0 & 0 & 50 & 25 & 25 & \multirow[t]{2}{*}{0.481} \\
\hline & & Control & 0 & 15 & 40 & 40 & 5 & \\
\hline \multirow[t]{2}{*}{8.} & \multirow{2}{*}{$\begin{array}{l}\text { Some bacteria } \\
\text { are getting } \\
\text { harder to use } \\
\text { antibiotics }\end{array}$} & Intervention & 0 & 0 & 0 & 50 & 50 & \multirow[t]{2}{*}{0.107} \\
\hline & & Control & 0 & 10 & 10 & 65 & 15 & \\
\hline \multirow[t]{2}{*}{9.} & \multirow{2}{*}{$\begin{array}{l}\text { Some bacteria } \\
\text { can become } \\
\text { resistant to } \\
\text { antibiotics if } \\
\text { the dose is } \\
\text { insufficient }\end{array}$} & Intervention & 0 & 0 & 0 & 50 & 50 & \multirow[t]{2}{*}{0.183} \\
\hline & & Control & 0 & 0 & 30 & 45 & 25 & \\
\hline
\end{tabular}


Table 2

Questions on experience with antibiotics with PAPA scale

Question
Group

Strongly

disagree

(\%)
Disagree

(\%)

Intervention $\quad 75$

Control

reduce the

dose of

antibiotics. condition feels

better, I can

25

20

65
Neutral

(\%)

Agree

(\%) Strongly agree

(\%)
P value

1. If my child's

2. If my child is mild, I will give appropriate antibiotics according to the condition.
25

0

0

0

15

Control

25

55

0

$0 \quad 0$

0.039 *

3. There is no difference in skipping the dose of one or two antibiotics.

4. If your child
has symptoms Intervention $\quad 75$

25

0

0

0

0.142

Control

35

55

5

5

0

of cough, cold or flu without taking antibiotics, my child will not Intervention $\quad 50$

25

25

0

0

0.235 get sick for a long time.

5. If my child has Intervention 50 a cold or cough, it is best to use antibiotics to Control 15 45 30 10

0 cure

6. When a child has a cold, using antibiotics can speed up Control 20

25

25

$0 \quad 0$

0.384

healing

7. Strict adherence to antibiotic dose is not Intervention $\quad 25$

$25 \quad 50$

50

25

50

important

Control

20

25

25

0

0.280

Intervention

75

25

25

30

0

Control

35

50

0

0

0

0.137 . 
In one item of the PAPA scale that asked if parents agreed that some bacteria could become resistant to antibiotics if the dose was insufficient, $25 \%$ of the parents in the intervention group chose "neutral" (neither agree nor disagree) before the program and $100 \%$ of them chose either "agree" or "strongly agree" after the program. On the other hand, the control group had $30 \%$ of the parents chose "neutral" to this item both before and after the two weeks. However, there was no significant difference between the two groups.

The parents' usage of the Facebook Page on Antibiotic Use was aligned with the data obtained from the PAPA scale questionnaire in that more than half of the parents obtained health-related information from the Internet. Through the Facebook Audience Insight Tool, the participants' behavior on the Facebook page was tracked. The page was a success and it was visited more than a hundred times a week with activities like posting messages and comments, and interacting with peers about antibiotic use. On analysis, a strong negative correlation was found between social support and parents' belief that antibiotics could cure their children's cold symptoms, with Pearson coefficient of -1 and $p=0.001$, implying that they had learnt that antibiotics are not for colds. There was a significant difference and a strong negative correlation between social media and the parents' belief that antibiotics could be stopped when their children felt better, with Pearson coefficient of -0.78 and $p=0.001$, implying that the program could change the parents' belief to proper antibiotic use (Table 3 ).

Table 3

How to get health-related information table of correlations in parents

\begin{tabular}{|llllll|}
\hline Question & Mean & SD & $\mathbf{1}$ & $\mathbf{2}$ & $\mathbf{3}$ \\
\hline 1. $\begin{array}{l}\text { I get health-related information from my family } \\
\text { or friends. }\end{array}$ & 3.40 & 0.598 & 1.000 & & \\
\hline 2. $\quad$ I get health related information from the internet & 3.50 & 0.688 & 0.128 & 1.000 & \\
\hline $3 . \quad \begin{array}{l}\text { I get health-related information from the social } \\
\text { media. }\end{array}$ & 3.45 & 0.887 & 0.139 & $0.733^{\star *}$ & 1.000 \\
\hline$* * p<0.005$ & & & & & \\
\hline
\end{tabular}

Item 1 of the GSE scale asked if it was true that the parents could always manage to solve difficult problems if they tried hard enough. It was found that no one in the intervention group regarded this statement as "exactly true" before the training; however, after the program, $25 \%$ of them agreed to the statement. In the control group, the percentage of parents responding as "exactly true" decreased from $15-10 \%$ after the two weeks. On the whole, there was no significant difference between the two groups with respect to the GSE scale (Table 4). 
Table 4

Summary of General Efficacy Scale (GES)

\begin{tabular}{|c|c|c|c|c|c|c|c|}
\hline & Question & Group & $\begin{array}{l}\text { Not } \\
\text { at } \\
\text { all } \\
\text { true } \\
(\%)\end{array}$ & $\begin{array}{l}\text { Hardly } \\
\text { true } \\
\text { (\%) }\end{array}$ & $\begin{array}{l}\text { Moderately } \\
\text { true (\%) }\end{array}$ & $\begin{array}{l}\text { Exactly } \\
\text { true } \\
(\%)\end{array}$ & $\begin{array}{l}\mathrm{P} \\
\text { value }\end{array}$ \\
\hline \multirow[t]{2}{*}{1.} & \multirow{2}{*}{$\begin{array}{l}\text { I can always manage to } \\
\text { solve difficult problems if I } \\
\text { try hard enough }\end{array}$} & Intervention & 0 & 25 & 50 & 25 & \multirow[t]{2}{*}{0.421} \\
\hline & & Control & 5 & 35 & 50 & 10 & \\
\hline \multirow[t]{2}{*}{2.} & \multirow{2}{*}{$\begin{array}{l}\text { If someone opposes me, I } \\
\text { can find the means and } \\
\text { ways to get what I want }\end{array}$} & Intervention & 0 & 50 & 50 & 0 & \multirow[t]{2}{*}{0.429} \\
\hline & & Control & 10 & 60 & 25 & 5 & \\
\hline \multirow[t]{2}{*}{3.} & \multirow{2}{*}{$\begin{array}{l}\text { It is easy for me to stick to } \\
\text { my aims and accomplish } \\
\text { my goals }\end{array}$} & Intervention & 0 & 50 & 50 & 0 & \multirow[t]{2}{*}{0.580} \\
\hline & & Control & 0 & 35 & 65 & 0 & \\
\hline \multirow[t]{2}{*}{4.} & \multirow{2}{*}{$\begin{array}{l}\text { I am confident that I could } \\
\text { deal efficiently with } \\
\text { unexpected events }\end{array}$} & Intervention & 0 & 50 & 50 & 0 & \multirow[t]{2}{*}{0.727} \\
\hline & & Control & 5 & 35 & 55 & 5 & \\
\hline \multirow[t]{2}{*}{5.} & \multirow{2}{*}{$\begin{array}{l}\text { Thanks to my } \\
\text { resourcefulness, I know } \\
\text { how to handle unforeseen } \\
\text { situations }\end{array}$} & Intervention & 0 & 50 & 50 & 0 & \multirow[t]{2}{*}{0.678} \\
\hline & & Control & 20 & 35 & 40 & 5 & \\
\hline \multirow[t]{2}{*}{6.} & \multirow{2}{*}{$\begin{array}{l}\text { I can solve most problems } \\
\text { if I invest the necessary } \\
\text { effort }\end{array}$} & Intervention & 0 & 25 & 75 & 0 & \multirow[t]{2}{*}{0.353} \\
\hline & & Control & 0 & 15 & 65 & 20 & \\
\hline \multirow[t]{2}{*}{7.} & \multirow{2}{*}{$\begin{array}{l}\text { I can remain calm when } \\
\text { facing difficulties because I } \\
\text { can rely on my coping } \\
\text { abilities }\end{array}$} & Intervention & 0 & 25 & 75 & 0 & \multirow[t]{2}{*}{0.64} \\
\hline & & Control & 10 & 25 & 65 & 0 & \\
\hline \multirow[t]{2}{*}{8.} & \multirow{2}{*}{$\begin{array}{l}\text { When I am confronted with } \\
\text { a problem, I can usually } \\
\text { find several solutions }\end{array}$} & Intervention & 0 & 50 & 50 & 0 & \multirow[t]{2}{*}{$0.35^{-}$} \\
\hline & & Control & 5 & 20 & 70 & 5 & \\
\hline \multirow[t]{2}{*}{9.} & \multirow{2}{*}{$\begin{array}{l}\text { If I am in trouble, I can } \\
\text { usually think of a solution }\end{array}$} & Intervention & 0 & 50 & 50 & 0 & \multirow[t]{2}{*}{0.277} \\
\hline & & Control & 0 & 25 & 65 & 10 & \\
\hline \multirow[t]{2}{*}{10.} & \multirow{2}{*}{$\begin{array}{l}\text { I can usually handle } \\
\text { whatever comes my way }\end{array}$} & Intervention & 0 & 50 & 50 & 0 & \multirow[t]{2}{*}{0.614} \\
\hline & & Control & 5 & 35 & 45 & 15 & \\
\hline
\end{tabular}

\section{Discussion}

The aim of this pilot study was to test the feasibility of such a study at a regional level across Hong Kong. With a small sample size of 44 in this pilot, its analytical power is expected to be low and its predictions may be biased. However, we hope that this pilot can provide insights for the main study. 
In this pilot, it was found that the participants in the intervention group did a little better in understanding common colds do not need antibiotics. Although this finding does not show that the program had a significant impact on correcting the misconception of using antibiotics for curing colds, yet the effect is expected to be significant when the study uses a large enough sample size. Another support for the main study is that the participants' knowledge of using antibiotics for viral infections had a significant improvement for the intervention group over the control group. This result was similar to that of Ekambi et al.'s study. ${ }^{12}$ Another finding is that the knowledge on bacteria becoming more resistant to antibiotics was similar for both groups. This may provide insights to the modification of the education program. On the item that insufficient dose of antibiotics being the cause of antimicrobial resistance, the intervention group did a lot better than the control group. This finding coincides with the hypothesis of the study. Since both groups could not differentiate viral, bacterial and fungal infections, nor understand the effect of skipping antibiotics dosage in a medication course, and were not sure about whether antibiotics help speed up healing colds, we should further strengthen the design of our education program to achieve the desired results.

All in all, the pilot showed that parents learnt the basic knowledge on proper and inappropriate antibiotic uses with respect to antimicrobial resistance. The education program, however, should be enhanced in view of the difficulties the parents had in answering questions related to cold and cough symptoms. This study supported the findings that family and friends did influence medication taking. ${ }^{13}$ Moreover, this study also demonstrated that parents' behavior was influenced by social support. ${ }^{14}$ Our findings demonstrated that parents who were active in the social media were able to learn correct information on antibiotics in ways that other studies had not. ${ }^{15}$

Parents' perception of their self-efficacy affected their behavior. Parents valued consistent advice from a trusted source that could address their common concerns and help their decision making. Our findings showed an increase in parental self-efficacy scores after the training program in the intervention group while parental self-efficacy scores decreased in the control group. This result was similar to that of Gross et al. ${ }^{16}$. which found a trend of growing parental self-efficacy in their parent training groups as compared to those in the control groups though the difference was not statistically significant. It is necessary to increase parental self-efficacy to support the development of knowledge and communication skills on antibiotic use ${ }^{17}$ because one study had shown that parents with low self-efficacy were not able to put parenting knowledge into practice. ${ }^{18}$

\section{Conclusion}

This pilot yielded positive preliminary results on improving basic knowledge of antibiotic use to reduce antimicrobial resistance. It also demonstrates that peer support could increase the self-efficacy of the parents to enhance their learning in these medication issues. Based on the findings in this pilot study, a further study based on the education program with enhancement and peer support can be implemented in a large scale with a positive expectation of reducing antimicrobial resistance. 


\section{Declarations}

\section{Acknowledgments}

We would like to thank all participating kindergartens for their efforts during the study.

\section{Authors' contributions}

P.P.L.Or is the first author and corresponding author. P.P.L.Or and P.T.Y.Ching defined the study design, developed the intervention materials and conducted the data collection. P.P.L.Or performed the data analysis and drafted the manuscript with the input of P.T.Y.Ching. The authors read and approval the final manuscript.

\section{Funding}

This work was internally funded by Dean's research fund of the Faculty of Liberal Arts and Social Sciences, the Education University of Hong Kong. The funder had no role in the design of the study, data collection, analysis, interpretation of data, in writing and its submission for publication.

\section{Availability of data and materials}

The datasets used and/or analysed during the current study are available from the corresponding author on request.

\section{Ethics approval and consent to participate}

The study was approved by the ethics commission of the Education University of Hong Kong (Ref.no.2018-2019-0122).

\section{Consent for publication}

Not applicable

\section{Competing interest}

The authors declare that they have no competing interests.

\section{Author details}

${ }^{1}$ Department of Health and Physical Education, The Education University of Hong Kong. 10 Lo Ping Road, Tai Po, New Territories, Hong Kong

2 Senior Nurse, WHO Collaboration Centre for Infectious Disease Epidemiology and Control, The School of Public Health, The University of Hong Kong. 7 Sassoon Road, Sandy Bay, Hong Kong 


\section{References}

1. Mehta N, Schilder A, Fragaszy E, E. R. Evans H, Dukes O, Manikam L, et al. Antibiotic prescribing in patients with self-reported sore throat. J Antimicrob Chemother. 2017 72:914-922. doi.org/10. 1093/jac/dkw497 PMID: 27999063

2. European Commission, 2010. Special Eurobarometer 445 Antimicrobial resistance report. Available from https://ec.europa.eu/health/amr/sites/health/files/antimicrobial_ resistance/docs/eb445_amr_generalreport_en.pdf [cited 2019 Dec 2]

3. Lam TP, Lam KF, Ho PL, Yung R. Knowledge, attitude and behavior toward antibiotics among Hong Kong people: Local-born versus immigrants. Hong Kong Medical Journal 2015. 21;7:41-47.

4. Zarb P, Goossens H Human use of antimicrobial agents. RevueScientifique et Technique 2012; 31:121-33.

5. Alumran A., Hou X, Hurst C. (2013). Assessing the overuse of antibiotics in children in Saudi Arabia: Validation of the parental perception on antibiotics scale (PAPA scale) Health and Quality of Life Outcomes. 2013 March;11:39. Doi:10.1186/1477-7525-11-39.

6. Wang H, Wang B, Zhao Q, et al. Antibiotic body burden of Chinese school children: a multisite biomonitoring-based study. Environmental Science Technology 2015;49: 5070-79.

7. Al-Hassan MI. Community pharmacy practice in Saudi Arabia: an overview. The Internet Journal of Pharmacology. 2011;9Available from: http://ispub.com/IJPHARM/9/1/5301 [cited 2019 Jun 16]

8. Hawkings NJ, Butler CC, Wood F. Antibiotics in the community: a typology of user behaviors. Patient Education and Counseling 2008;73:146-52.

9. Laxminarayan et al. Antibiotics resistance-the need for global solutions. The Lancet Infectious Disease Commission 2013. 17;13:70318-9. Doi.org/10.1016/S1473-3099

10. World Health Organization. Peer Support programmes in diabetes. Report of a WHO consultation, 5-7 November 2007. Retrieved from https://www.who.int/diabetes/publications/Diabetes_final_13_6.pdf

11. Yildirim F, Ilhan I. The validity and reliability of the general self-efficacy scales Turkish form. Turkish Journal of Psychiatry 2010;21:301-8.

12. Ekambi E, Ebongue O, Penda C, Nga EN, Mpondo EM, Moukoko CE. Knowledge, practices and attitudes on antibiotics use in Cameroon: Self-medication and prescription survey among children, adolescents and adults in private pharmacies. PLOS One doi.org/10.1371/journal.pone.0212875

13. Cheraghi-Sohi S, Jeffries M, Stevenson F, Ashcroft DM, Carr M, Oliver K, Rogers A. (2015). The influence of personal communities on the self-management of medication taking: a wider exploration of medicine work. Chronic Illn. 2015 11;2: 77-92.

14. Hempler NF, Joensen LE, Willaing I. (2016). Relationship between social network, social support and health behaviour in people with type 1 and type 2 diabetes: cross-sectional studies. BMC Public Health 2016;16:198.

15. Ellis J, Vassilev I, Kennedy A, Moore M, Rogers A. Help seeking for antibiotics; is the influence of a personal social network relevant? BMC Family Practice 2019;20:63. org/10.1186/s12875-019-0955-2 
16. Gross D, Garvey C, Julion W, Fogg L, Tucker S, Mokros H. Efficacy of the Chicago parent program with low-income African American and Latino parents of young children. Prevention Science, 2009;10:5465.doi:1007/s11121-008- 0116-7.

17. Mouth B, Loop L, Stievenart M, Roskam I. Confident parents for easier children: A parental selfefficacy program to improve young children's behavior. Education Science 2018; 8:134. doi:10.3390/educsci8030134

18. Wittkowski A, Dowling H, Smith D. Does Engaging in a Group-Based Intervention Increase Parental Self-efficacy in Parents of Preschool Children? A Systematic Review of the Current Literature. J Child Fam Stud 25:3173-3191 doi:10.1007/s10826-016-0464-z 